\title{
Simulation of Ground-Water Flow in the High Plains Aquifer, Southern Sandhills Area, West-Central Nebraska
}

By J.S. McLean, H.H. Chen, and J.W. Goeke

U.S. GEOLOGICAL SURVEY

Open-File Report 96-206

Prepared in cooperation with the UNIVERSITY OF NEBRASKA, CONSERVATION AND SURVEY DIVISION, the TWIN PLATTE NATURAL RESOURCES DISTRICT, and the UPPER LOUP NATURAL RESOURCES DISTRICT

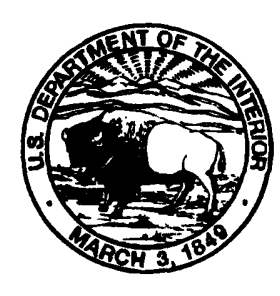

Lincoln, Nebraska 1997 


\title{
U.S. DEPARTMENT OF THE INTERIOR BRUCE BABBITT, Secretary
}

\author{
U.S. GEOLOGICAL SURVEY \\ GORDON P. EATON, Director
}

For additional information write to:

District Chief

U.S. Geological Survey

100 Centennial Mall North

406 Federal Building

Lincoln, NE 68505
Copies of this report can be purchased from:

U.S. Geological Survey

Branch of Information Services

PO Box 25286

Denver, CO 80225 


\section{CONTENTS}

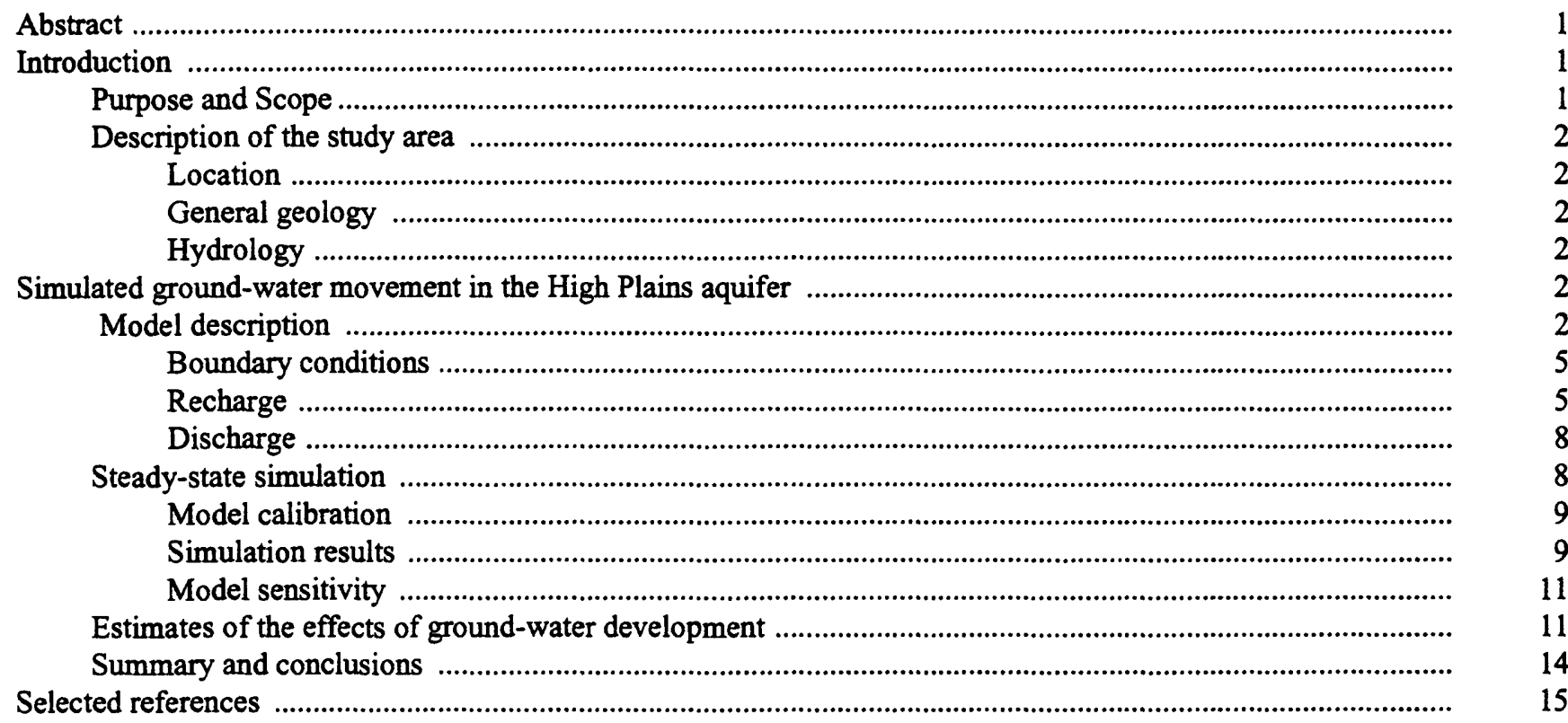

\section{Attachments (on diskettes at back of report):}

Attachment A--Initial model parameter arrays and results of steady-state simulation

B--Simulated water budget using the program ZONEBUDGET.

C--Results of simulation to estimate the effects of an increase in ground-water development on water levels in the High Plains aquifer.

D--Simulated water budget after 10 and 20 years of increased ground-water development

\section{FIGURES}

Figure 1. Location of the study area

2. Geologic section across the sandhills of Nebraska

3. Model grid and location of irrigation wells in which water levels were measured, winter 1982-83

4. Model boundaries and node classifications used in steady-state simulation

5. Measured and simulated water levels in the High Plains aquifer, southern sandhills, west-central Nebraska, winter 1982-83

6. Simulated water-level drawdown in wells in the southern sandhills, west-central Nebraska, after 10 years of pumping and assuming a specific yield of 16 percent

7. Simulated water-level drawdown in wells in the southern sandhills, west-central Nebraska, after 20 years of pumping and assuming a specific yield of 16 percent 


\section{TABLES}

Table 1. Simulated steady-state water budget for the High Plains aquifer in the study area

2. Measured (1978 and 1981) and simulated steady-state discharge to streams in the study area

3. Sensitivity of the steady-state model.

4. Simulated drawdown after 10 and 20 years of pumping at model row 7 , column 19 .

5. Simulated water budget for the High Plains aquifer in the study area after 20 years of pumping

6. Simulated discharge to streams in the study area after 20 years of pumping

\section{CONVERSION FACTORS AND VERTICAL DATUM}

\begin{tabular}{lcl}
\multicolumn{1}{c}{ Multiply } & By & \multicolumn{1}{c}{ To obtain } \\
acre & 4,047 & square meter \\
acre-foot $(\mathrm{acre}-\mathrm{ft})$ & 1,233 & cubic meter \\
cubic foot $\left(\mathrm{ft}^{3}\right)$ & 0.02832 & cubic meter \\
cubic feet per second $\left(\mathrm{ft}^{3} / \mathrm{s}\right)$ & 0.02832 & cubic meters per second \\
cubic feet per day $\left(\mathrm{ft}^{3} / \mathrm{d}\right)$ & 0.02832 & cubic meters per day \\
feet per day $(\mathrm{ft} / \mathrm{d})$ & 0.3048 & meters per day \\
square feet per day $\left(\mathrm{ft}^{2} / \mathrm{d}\right)$ & 0.09290 & square meters per day \\
foot ( $\mathrm{ft})$ & 0.3048 & meter \\
gallon (gal) & 3.785 & liter \\
gallons per minute $(\mathrm{gal} / \mathrm{min})$ & 0.06309 & liters per second \\
inch (in.) & 25.4 & millimeter \\
inches per year $(\mathrm{in} / \mathrm{yr})$ & 25.4 & millimeters per year \\
mile (mi) & 1.609 & kilometer \\
square mile $\left(\mathrm{mi}^{2}\right)$ & 2.590 & square kilometer
\end{tabular}

To convert degree Fahrenheit $\left({ }^{\circ} \mathrm{F}\right)$ to degree Celsius $\left({ }^{\circ} \mathrm{C}\right)$ use the following formula:

$$
\left.{ }^{\circ} \mathrm{C}=5 / 9 \text { ( }{ }^{\circ} \mathrm{F}-32\right) \text {. }
$$

Sea level: In this report "sea level" refers to the National Geodetic Vertical Datum of 1929 (NGVD of 1929)--a geodetic datum derived from a general adjustment of the first-order level nets of both the United States and Canada, formerly called Sea Level Datum of 1929.

The standard unit for transmissivity $(T)$ is cubic feet per day per square foot times foot of aquifer thickness $\left[\left(\mathrm{ft}^{3} / \mathrm{d}\right) / \mathrm{ft}^{2}\right] \mathrm{ft}$. In this report, this mathematical expression has been reduced to square feet per day $\left(\mathrm{ft}^{2} / \mathrm{d}\right)$. 


\title{
Simulation of Ground-Water Flow in the High Plains Aquifer, Southern Sandhills Area, West-Central Nebraska
}

\author{
By J.S. McLean ${ }^{1}$, H.H. Chen ${ }^{2}$, and J.W. Goeke ${ }^{3}$
}

\section{Abstract}

A generalized ground-water flow model was prepared for the High Plains aquifer in the southern sandhills area of west-central Nebraska. A grid of 4by 4 -mile nodes was established over the study area. Steady-state water levels were simulated using a distribution of recharge from a soil-moisture budget model and from estimates of hydraulic conductivity obtained from logs of test holes in the area. The final calibrated simulation used hydraulic-conductivity values that were 122 percent, and recharge rates that were 89 percent of the original values used in the model.

Sixty-seven percent of the simulated recharge to the High Plains aquifer discharges to rivers, streams, and lakes. Discharges through ground-water evapotranspiration and from pumping wells account for 20 percent, with the wells accounting for less than 10 percent of the total discharge, and subsurface boundary outflow accounts for 13 percent. Twenty years of simulated pumping, assuming one additional well would be added to each township annually for 10 years, and two wells per township would be added each year for the succeeding 10 years, produced a maximum simulated drawdown of less than 10 feet when a uniform specific yield of 16 percent for the aquifer in the study area was assumed.

\section{INTRODUCTION}

Prior to the 1980's, the southern sandhills area in west-central Nebraska had experienced little ground-water development for irrigated agriculture. During the late 1980's, however, a rapid increase in

\footnotetext{
${ }^{1}$ U.S. Geological Survey, Lakewood, Colorado.

${ }^{2}$ U.S. Geological Survey, Lincoln, Nebraska.

${ }^{3}$ University of Nebraska, Conservation and Survey Division, Lincoln, Nebraska.
}

the number of registered irrigation wells in the area raised questions about the effects of possible irrigation development on ground-water levels, lakes, and streams in the area. A five-year study was begun in 1981 by the U.S. Geological Survey in cooperation with the University of Nebraska, Conservation and Survey Division (CSD), the Twin Platte Natural Resources District (NRD), and the Upper Loup NRD to define the hydrologic framework and to provide additional hydrologic data for the area. The study activities included drilling test wells, measuring water levels, collecting rainfall data, collecting water samples for chemical analysis, and collecting data on the gain in the base flow of streams in the area (Johnson and others, 1986). The study also proposed to evaluate the water balance of the hydrologic system (part of the extensive High Plains aquifer) in the area so that the potential effects of ground-water development in the area could be evaluated.

\section{Purpose and Scope}

The purpose of this report is to present a simplified conceptual model of the High Plains aquifer system in the southern sandhills, to test the conceptual model using a simplified numerical model of groundwater flow, and to present estimates of the effects of widespread development on ground-water levels and the water budget. The report also makes the numerical model available for use by the cooperators and other interested parties. Because the southern sandhills area has experienced limited ground-water development and the actual pumping rates from the few irrigation wells in the area are unknown, and because the resources to conduct the study were limited, a simplified, rather than a detailed, numerical model was prepared to represent the general ground-water hydrology of the area. The model could not be calibrated to rep- 
resent transient conditions because there has been no large-scale development in the area and historical water-level measurements are sparse. Estimates of the effects of ground-water development are thus shown only to provide the reader with very general depictions of the possible continued effects of additional development and should not be viewed as specific predictions.

\section{Description of the Study Area}

\section{Location}

The study area encompasses $4,330 \mathrm{mi}^{2}$ in the southern part of the Nebraska sandhills and includes all of Arthur, Logan, and McPherson Counties and parts of Blaine, Hooker, Keith, Lincoln, and Thomas Counties (fig. 1). County lines form the eastern, western, and part of the northern boundaries of the area.

The Dismal River forms the rest of the northern boundary, and the South Platte and Platte Rivers form the southern boundary.

\section{General Geology}

The High Plains aquifer as defined by Gutentag and others (1984, p. 9) includes the Arikaree Group and Ogallala Formation of Miocene age and the overlying alluvial, loess, dune-sand, and valley-fill deposits of Pleistocene and Holocene age. The base of the aquifer is the Brule Formation or other units of the White River Group (fig. 2). Locally, the Brule Formation contains sand-filled fractures or channels that yield substantial quantities of water to wells (as much as $1,500 \mathrm{gal} / \mathrm{min}$ ), and where present, are considered part of the High Plains aquifer. The White River Group, which contains abundant mudstone and siltstone, is considered to be a confining unit. The High Plains aquifer consists of variable proportions of sand, silt, and gravel with minor amounts of silt and clay. Local beds of siltstone or claystone near the top of the Ogallala Formation form confining units; however, their effect on the flow system in the area is generally undocumented and assumed to be negligible.

\section{Hydrology}

The High Plains aquifer in the study area is considered to be an unconfined aquifer. Test holes indicate that the High Plains aquifer is more than $800 \mathrm{ft}$ thick in the north-central part of the study area and decreases to less than $100 \mathrm{ft}$ thick in the western part of the Platte River Valley. The High Plains aquifer is recharged primarily by precipitation. The stabilized sand dunes of the southern sandhills area transmit a substantial part of the precipitation as recharge to the water table. Surface-water irrigation provides additional recharge to the aquifer near the Platte and South Platte Rivers.

Ground-water flow north of the North Platte River generally is eastward and southward from the northwest part of the study area. Some of the ground water in the northwest and north-central part of the area discharges to lakes, springs, and wet meadows. The remainder moves eastward to the Dismal River and other streams in the eastern part of the area or southward to the Platte River and its tributaries. Irrigation wells withdraw water at scattered locations throughout the area, although most of the wells are concentrated near the Platte and South Platte Rivers.

\section{SIMULATED GROUND-WATER MOVE- MENT IN THE HIGH PLAINS AQUIFER}

A general numerical ground-water flow model of the High Plains aquifer was prepared to help evaluate the water budget of the study area and to provide estimates of the effects of potential large-scale well development on ground-water levels and the water budget. Rather than simulating local hydraulic conditions in detail, only the general, regional conditions of the aquifer were simulated. A modular, finite-difference model (McDonald and Harbaugh, 1988) was used in the simulation, and the model arrays and results can be obtained on diskette from the U.S. Geological Survey, Lincoln, Nebraska.

\section{Model Description}

The ground-water system in the study area was simulated using a single-layer, coarse model grid (fig. 3). The area was divided into nodes using an array of 19 rows and 29 columns, for a total of 551 nodes. Each node is $4 \mathrm{mi} \times 4 \mathrm{mi}$. The modular model used consistent units of measurement for the model parameters; feet were used for units of length, and days were used for units of time. The model documentation found in McDonald and Harbaugh (1988) should be used when interpreting the model results. 

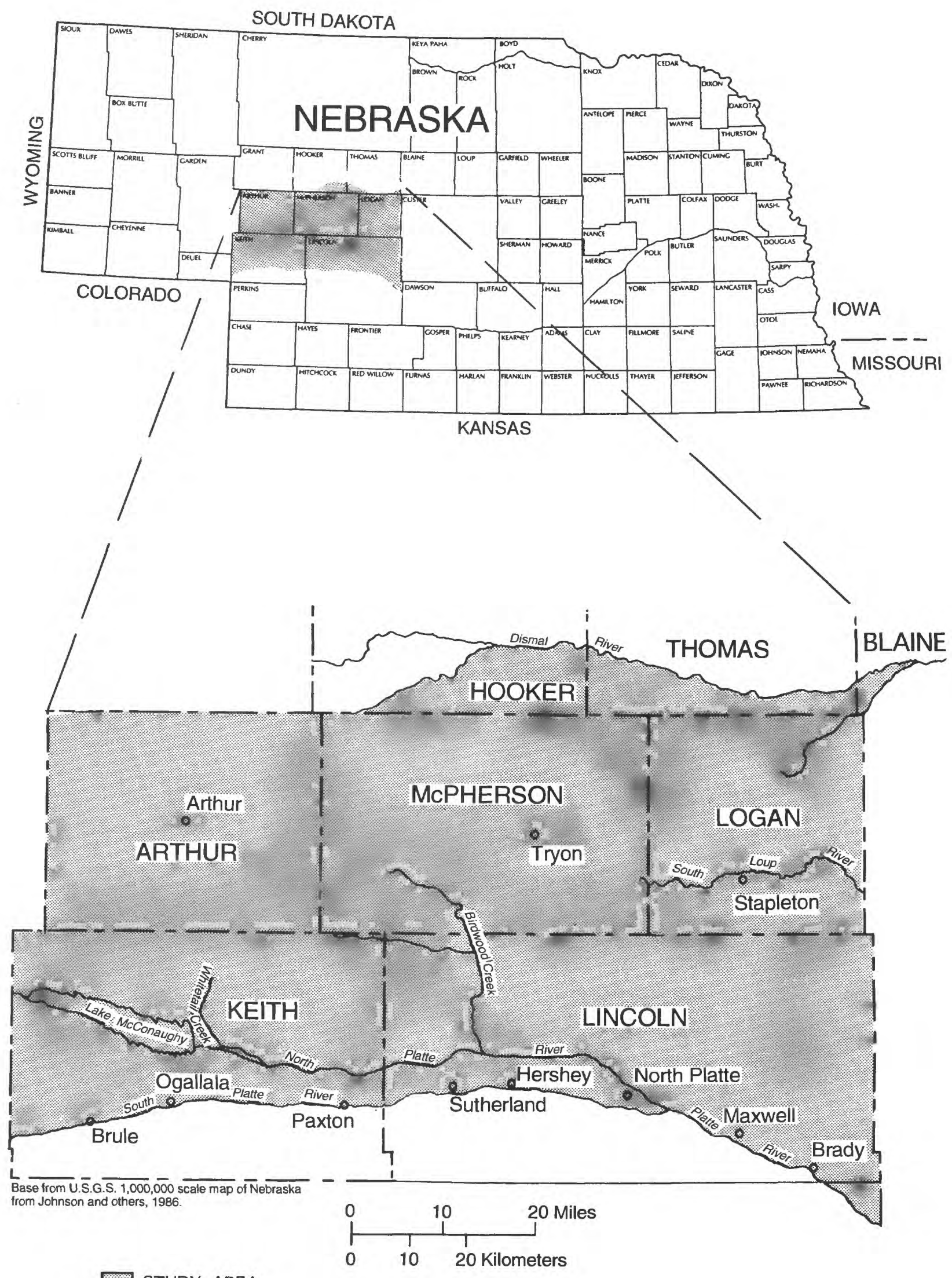

STUDY AREA

Figure 1. Location of the study area. 


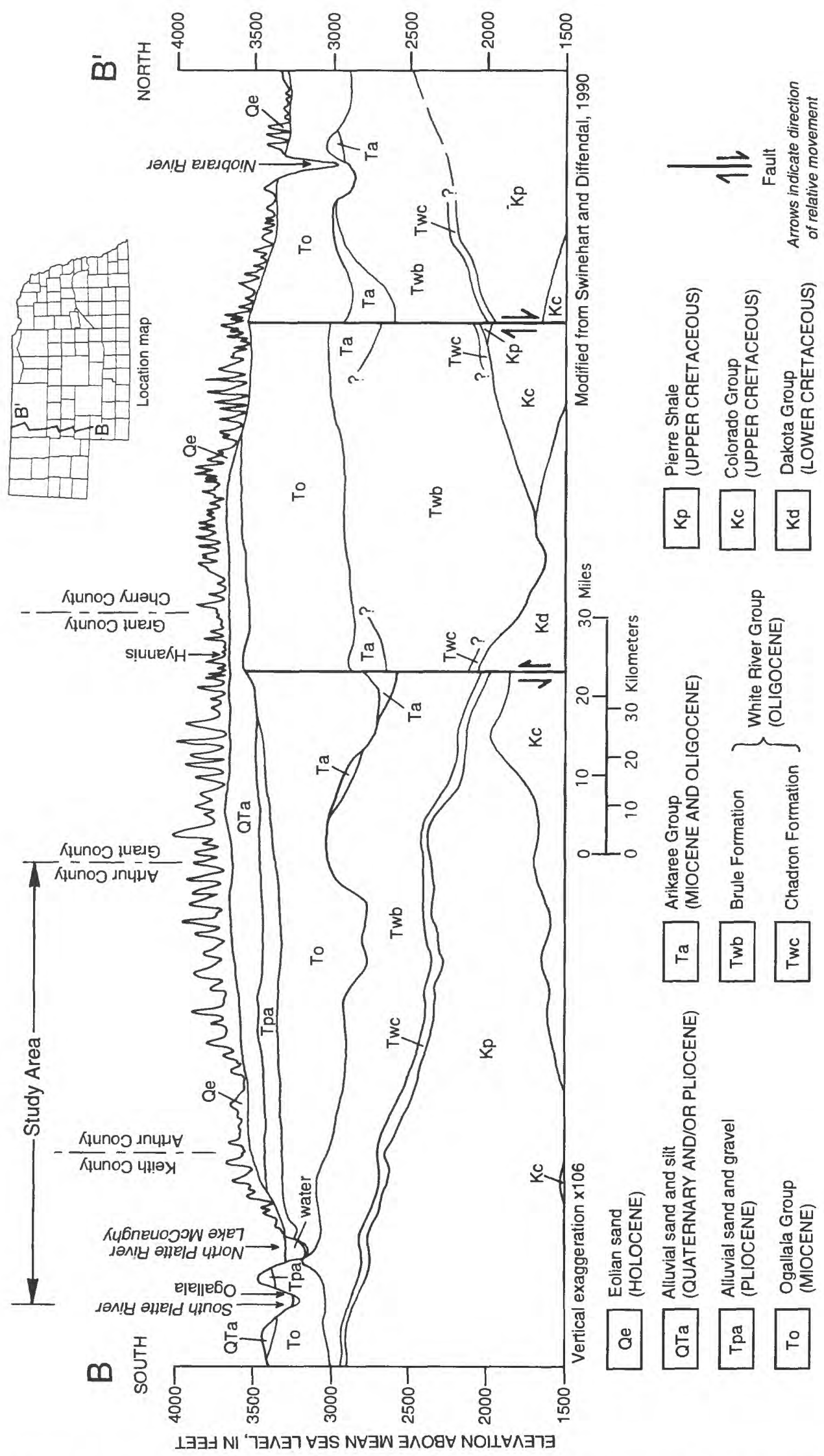

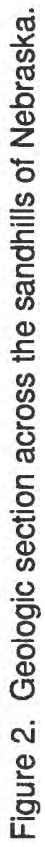


Initial saturated thickness ranged from more than 950 feet in the north-central part of the area to less than $\mathbf{1 5 0}$ feet in the southwest part of the area between the North and South Platte Rivers.

The average hydraulic conductivity of the High Plains aquifer at each of 64 test wells (Johnson and others, 1986) was estimated from the lithologic description in the well log using the estimates of hydraulic conductivity given in table 7 of Goeke and others (1992). The resulting initial model array of average hydraulic conductivities is shown in attachment $\mathrm{A}$ in units of feet per day.

\section{Boundary Conditions}

Because only a small part of the extensive High Plains aquifer was simulated, it was not possible to extend the model to natural aquifer boundaries at all margins. However, the model grid was extended beyond the limits of the study area to minimize the effect of the model boundaries on the simulation results. The base of the aquifer was simulated as an impermeable boundary and was represented by a model array (attachment A) of the altitudes of the top of the White River Group, which were determined from the logs of 64 test wells given in Johnson and others (1986) and from Diffendal (1991). All attachments are provided in machine-readable (ASCII) format on the diskette in the back of the report. The upper boundary of the simulated system was represented by the water table. Flow along the northern margin of the modeled area is generally from west to east, approximating a flow line, so that margin was treated as an impermeable, inactive boundary for the most part (fig. 4). A part of the western boundary north of the North Platte River approximately follows a ground-water divide and was also simulated as an impermeable, inactive boundary. The southern boundary of the study area coincides with the South Platte River west of the confluence of the North and South Platte Rivers and with the Platte River east of the confluence. Because the South Platte and Platte Rivers are large and are hydraulically connected to the aquifer, the rivers were considered to be the southern boundary of the active model, and nodes south of the rivers were made inactive (fig. 4).

Flow enters the modeled area along the western boundary between the North and South Platte Rivers and leaves the area along the eastern boundary. These flows were simulated using general-head boundary nodes (McDonald and Harbaugh, 1988, p. 11-1 to 11-27) (fig. 4). Hydraulic conductivities for the boundary nodes were based on the initial hydraulic conductivities estimated from lithologic descriptions of the 64 test wells (Johnson and others, 1986) and ranged from 26.8 to $30.5 \mathrm{ft} / \mathrm{d}$ on the western boundary and from 29.2 to $49.9 \mathrm{ft} / \mathrm{d}$ on the eastern boundary. The hydraulic heads were assigned $8 \mathrm{mi}$ outside of the boundary nodes, allowing simulated water levels at the boundaries to change in response to well pumping, if necessary.

Internal boundaries in the model included the Platte, North Platte, and South Platte Rivers and several smaller streams (fig. 4). The Platte, North Platte, and South Platte Rivers were simulated using river nodes (McDonald and Harbaugh, 1988, p. 6-1 to 6-36) in the model. Small streams in the area, including the Dismal River, Blue Creek, Whitetail Creek, Birdwood Creek and its tributaries, the North Loup River, and the South Loup River (fig. 4), were simulated using drain nodes (McDonald and Harbaugh, 1988, p. 9-1 to 9-29). Drain nodes simulate flow only from the aquifer to the stream, thus allowing the model to simulate the stream going dry when nearby pumping reverses the gradient between the aquifer and the stream. Lake McConaughy was simulated using four constant-head nodes (fig. 4). For the purposes of this general model, the water level of the lake was assumed to be maintained at a constant altitude of $3,250 \mathrm{ft}$.

\section{Recharge}

The initial estimates of recharge were provided by J.T. Dugan (U.S. Geological Survey, written commun., 1993) using 50-year climatic records applied to a soil-moisture budget model (Pettijohn and Chen, 1983a, b; Dugan and Zelt, in press). The soil-moisture budget model uses hydrometeorological, soil, vegetation, and topographical data to estimate the long-term deep percolation through the unsaturated zone. The resultant recharge rates, shown in attachment $A$, were applied to the model area and were modified during model calibration. Irrigated areas within the modeled area were small relative to the entire area simulated, so the values of recharge were not modified for irrigated areas to account for variations in recharge from deep percolation of irrigation water. 


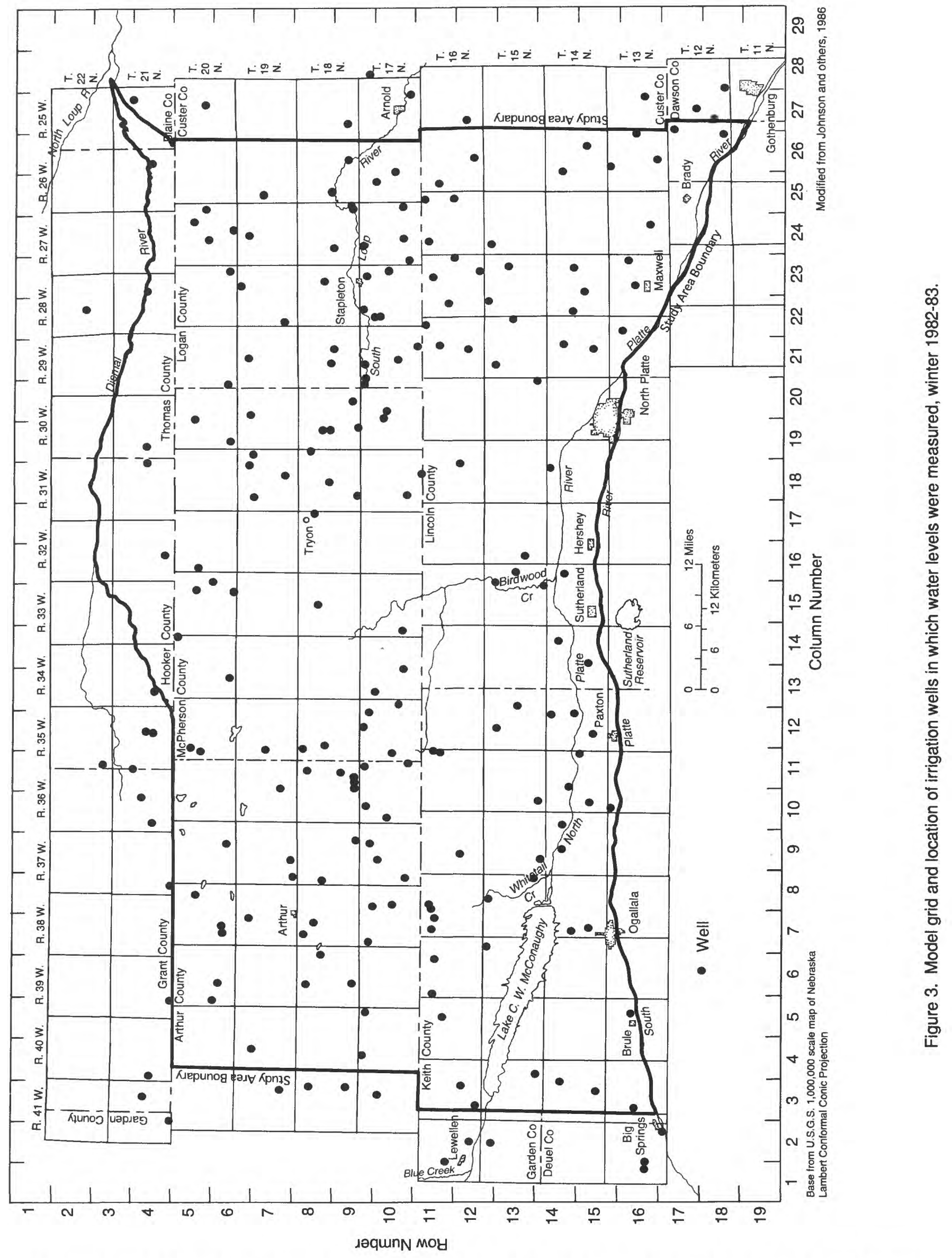

6 SIMULATION OF GROUND-WATER FLOW IN THE HIGH PLAINS AQUIFER, SOUTHERN SANDHILLS AREA, WEST-CENTRAL NEBRASKA 


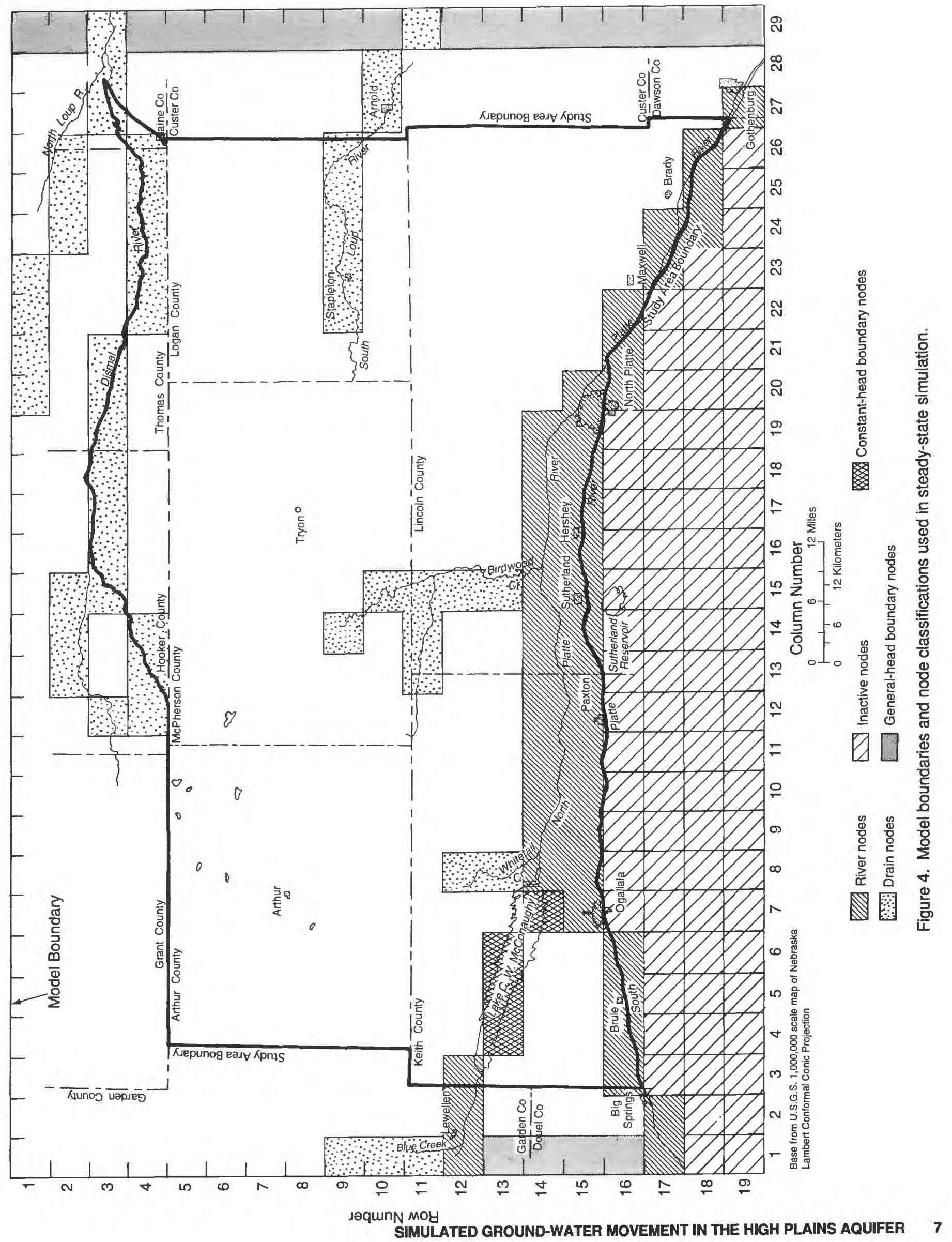




\section{Discharge}

Water is discharged from the High Plains aquifer by seepage to rivers and creeks, by pumping from wells, by transpiration from phreatophytes, and by evaporation from permanent, seasonal, or ephemeral lakes and wetlands supplied by ground water. Evaporation and transpiration usually are combined and termed evapotranspiration. Measurements of baseflow gain were made on the South Loup River in September 1978, on the Dismal River in October 1978, and on Whitetail and Birdwood Creeks in November 1981. These measurements were assumed to represent average long-term ground-water discharge. Measured base flow of the streams was compared with the simulated flow in the drain nodes representing these streams using the program ZONEBUDGET (Harbaugh, 1990). The simulation results for these and other nodes, as summarized by ZONEBUDGET, are shown in attachment $B$ (on diskette). Measurements of flow to the North and South Platte Rivers are complicated by stream diversions and return flows. Also, the rivers receive ground-water flow from outside the study area. Therefore, flows for these rivers were not used in model calibration.

Pumpage from wells in the study area has not been measured systematically; however, it represents only a small part of the total water budget for the area. Almost all pumpage in the area is used by center-pivot irrigation systems that each supply water to about 135 acres. Pumpage for each node was estimated by counting the number of registered irrigation wells in the node area and multiplying the number of wells by an average daily pumping rate per well of $700 \mathrm{gal} / \mathrm{min}$. The average pumping time is reportedly (Kent Miller, Twin Platte Natural Resources District, oral commun., 1996) 60 days per year, so that the total amount of water applied per well per year would average 700 $\mathrm{gal} / \mathrm{min}$ X 60 days $\times 1,440 \mathrm{~min} / \mathrm{d} \times 3.069 \times 10^{-6}$ acre$\mathrm{ft} / \mathrm{gal}$, or 185.6 acre-ft.

The application rate of 185.6 acre-ft per year divided by 135 acres would be $1.375 \mathrm{ft}$ or 16.5 in . Twenty percent of the $16.5 \mathrm{in}$. of water is assumed to return to the aquifer by deep infiltration; therefore, 13.2 in. is assumed to be actually consumed. Pumpage for a typical irrigation well would then be $700 \mathrm{gal} / \mathrm{min}$ x 60 days $\times 1,440 \mathrm{~min} / \mathrm{d}$ x $1 / 7.48 \mathrm{ft}^{3} / \mathrm{gal}$, or $8.086 \mathrm{x}$ $10^{6} \mathrm{ft}^{3}$. The consumptive use is 20 percent less, or $6.47 \times 10^{6} \mathrm{ft}^{3}$, and the average annual rate of con- sumptive use for the pumping rate used in the model is $6.47 \times 10^{6} \mathrm{ft}^{3}$ divided by 365 days per year and results in an average daily pumping rate of about $17,700 \mathrm{ft}^{3} / \mathrm{d}$ per well. Because not all registered irrigation wells are used in a given year, this method generally overestimates the total pumpage.

The valleys of the North Platte, South Platte, and Platte Rivers have been developed extensively for surface- and ground-water irrigation. The complex interaction of canals, drains, and wells is not simulated in the model, and the river nodes represent only the approximate interaction of the ground-water system with the surface-water bodies. Thus, wells were not simulated in the river nodes. Similarly, an area represented by the southeastern corner of the model contains many irrigation wells in an area served by canals carrying surface water. For the generalized groundwater flow model described herein, it was assumed that the infiltration from the applied surface water and the ground-water pumpage were approximately equal, so that pumpage was not simulated for the area represented by model rows 18 and 19 and columns 27 through 29.

The net excess of potential evapotranspiration over precipitation is estimated to be about $20 \mathrm{in} / \mathrm{yr}$ in the area south of the South Platte River (Goeke and others, 1992), and this value was used to estimate the maximum potential ground-water evapotranspiration in the study area. The evapotranspiration rate was limited to a maximum of 20 percent of the maximum potential rate because visual inspection of maps of the southern sandhills area indicated that no more than 20 percent of the total area of most nodes contained lakes or wetlands. The rate of evapotranspiration is assumed to decrease linearly to zero at a pre-selected "extinction" depth. This depth initially was set at $10 \mathrm{ft}$ and was adjusted during model calibration.

\section{Steady-State Simulation}

The model was extended beyond the boundaries of the study area to minimize the effects of the model boundaries on the solution within the study area. ZONEBUDGET (Harbaugh, 1990) was used to provide a simulated water budget for the study area, whereas MODFLOW (McDonald and Harbaugh, 1988) simulated the water budget for the entire modeled area. The model was calibrated to provide the best agreement between measured and simulated 
hydraulic heads and base flows in the study area, with less emphasis on the heads and flows outside the study area.

\section{Model Callbration}

The steady-state simulation was conducted by adjusting the recharge by fractions of the initial value until the total simulated base flow of the Dismal River, South Loup River, Birdwood Creek, and Whitetail Creek approximated the total measured base flow. The hydraulic conductivity was simultaneously adjusted by fractions of the initial value to maintain the mean error (mean difference between measured and simulated water levels) near zero. Thus, although the values of recharge and hydraulic conductivity were changed, the relative distribution of each was not. The maximum rate and extinction depth of evapotranspiration then were adjusted to minimize the mean absolute error (mean of the absolute differences between measured and simulated water levels). The conductance of individual drain nodes was adjusted to minimize the differences between measured and simulated base flows in individual streams and creeks. An implicit assumption is that the High Plains aquifer is in dynamic equilibrium for which a steady-state simulation of the water levels in the winter of 1982-83 and base flow gains in the fall of 1978 and 1981 are a good approximation. This assumption is supported by longterm water levels in the area that show no systematic decline and thus imply no long-term decreases in storage.

The original array of hydraulic-conductivity estimates was increased by 22 percent in the steadystate simulation, and the array of recharge estimated from the soil-moisture budget model was decreased uniformly to 89 percent of the original values to provide the best fit. The mean absolute error decreased slightly as evapotranspiration was increased up to the maximum potential evapotranspiration. Because the error due to evapotranspiration could not be minimized during calibration, the maximum rate of evapotranspiration was limited to a maximum of about $4 \mathrm{in} / \mathrm{yr}$ for each node, and the depth at which groundwater evapotranspiration ceased was simulated as $3.3 \mathrm{ft}$.

\section{Simulation Results}

The steady-state simulation generally reproduced the measured winter 1982-83 water levels (fig. 5) and 1978 and 1981 base flows in the study area. The average error (measured head minus simulated head) for the 295 nodes in the study area was $-0.3 \mathrm{ft}$, the absolute error (the sum of the errors for all active nodes, regardless of sign) was $14.06 \mathrm{ft}$, and the mean-squared error was $381 \mathrm{ft}$. The largest errors were in the north-central part of the study area, south of the Dismal River, and along the southwestern margin of the study area between the North Platte and South Platte Rivers. The model was unable to reproduce an area of elevated water levels south of the Dismal River accurately. This is in an area of sparse water-level data, and the reason for the elevated water levels is not understood.

The water budget simulated for the study area (Flow Budget for Composite Zone A at Time Step 1 of Stress Period 1, p. B-4, B-5) is shown in attachment B, in cubic feet per day, and in table 1 , converted to cubic feet per second. The simulated water budget for the entire model area (Volumetric Budget for Entire Model at End of Time Step 1 in Stress Period 1, p. A-9) is shown in attachment $A$, in cubic feet per day.

Table 1. Simulated steady-state water budget for the High Plains aquifer in the study area

[Values are in cubic feet per second]

\begin{tabular}{|c|c|c|c|}
\hline Budget item & $\begin{array}{c}\text { INFLOW } \\
\text { (Recharge) }\end{array}$ & Budget item & $\begin{array}{c}\text { OUTFLOW } \\
\text { (Discharge) }\end{array}$ \\
\hline Constant head & 11 & Constant head & 64 \\
\hline Rivers & 15 & Rivers & 377 \\
\hline $\begin{array}{l}\text { Boundary } \\
\text { inflow }\end{array}$ & 179 & $\begin{array}{l}\text { Boundary out- } \\
\text { flow }\end{array}$ & 173 \\
\hline \multirow{3}{*}{$\begin{array}{l}\text { Recharge } \\
\text { from pre- } \\
\text { cipitation }\end{array}$} & 1,129 & Wells & 126 \\
\hline & & Drains & 452 \\
\hline & & $\begin{array}{l}\text { Evapotranspi- } \\
\text { ration }\end{array}$ & 143 \\
\hline Total & 1,334 & Total & 1,335 \\
\hline
\end{tabular}




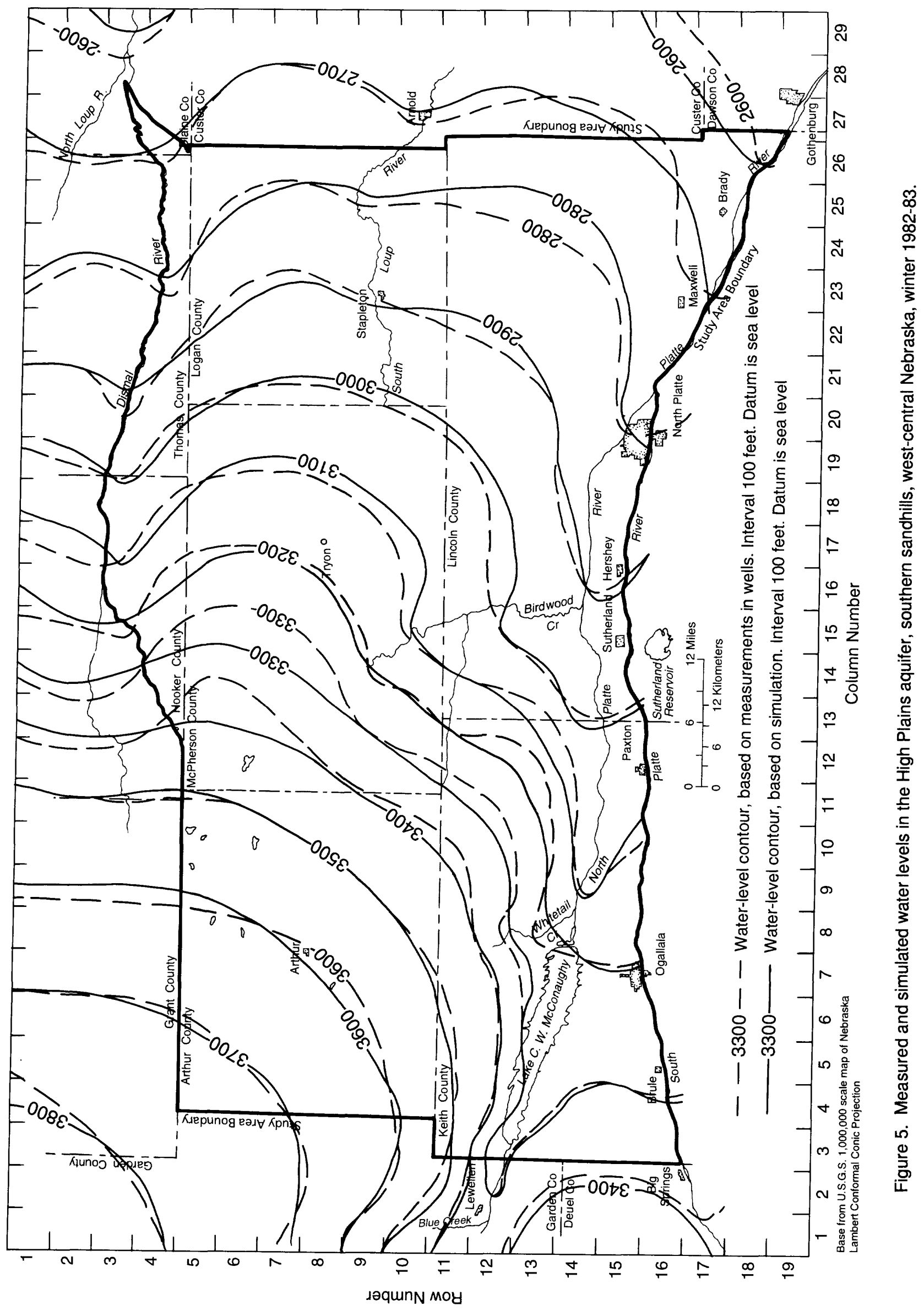


Recharge from precipitation $\left(1,129 \mathrm{ft}^{3} / \mathrm{s}\right)$ in the study area is nearly balanced by outflow to drains, rivers, evapotranspiration, and wells $\left(1,098 \mathrm{ft}^{3} / \mathrm{s}\right)$. Lateral subsurface inflow at the boundaries of the study area is approximately balanced by outflow. Discharge to small streams (represented by drains in the model), major rivers (represented by river nodes), and Lake McConaughy (represented by constant-head nodes) accounts for 67 percent of the discharge from the High Plains aquifer in the study area. Ground-water evapotranspiration and pumping wells account for 20 percent and boundary outflow accounts for 13 percent.

Total measured and simulated discharges to four streams are shown in table 2. Measured and simulated discharges coincide for three of the four streams. The model overestimates discharge to the South Loup River; however, a large gain in flow was measured just east of the study area, where the flow was $20 \mathrm{ft}^{3} / \mathrm{s}$ (as compared with a simulated discharge of $24 \mathrm{ft}^{3} / \mathrm{s}$ in table 2), suggesting that local heterogeneous characteristics of the aquifer may have caused diversion of water that otherwise would have discharged in the simulated reach.

Table 2. Measured (1978 and 1981) and simulated steadystate discharge to streams in the study area

[Values in cubic feet per second]

\begin{tabular}{lcc}
\hline \multicolumn{1}{c}{ Stream } & $\begin{array}{c}\text { Measured } \\
\text { discharge }\end{array}$ & $\begin{array}{c}\text { Simulated } \\
\text { discharge }\end{array}$ \\
\hline Dismal River & 250 & 251 \\
Birdwood Creek & 148 & 148 \\
South Loup River & 11 & 24 \\
Whitetail Creek & 29 & 29 \\
\hline
\end{tabular}

\section{Model Sensitivity}

The sensitivity of the model, expressed as the mean absolute error, in feet, to fractional changes in hydraulic conductivity, recharge rate, maximum depth of evapotranspiration, and maximum rate of evapotranspiration is shown in table 3 . The model is most sensitive to increases in recharge and decreases in hydraulic conductivity and is generally insensitive to small changes in the maximum depth of evapotranspiration.
Table 3. Sensitivity of the steady-state model

[Mean absolute error, in feet; --, not applicable]

\begin{tabular}{lccc}
\hline & \multicolumn{3}{c}{ Mean absolute error } \\
\cline { 2 - 4 } \multicolumn{1}{c}{ Parameter } & $\begin{array}{c}\text { Initial } \\
\text { value of } \\
\text { parameter }\end{array}$ & $\begin{array}{c}\text { Decrease of } \\
\mathbf{1 0} \\
\text { percent in } \\
\text { parameter } \\
\text { value }\end{array}$ & $\begin{array}{c}\text { Increase of } \\
\mathbf{1 0} \text { percent } \\
\text { In parameter } \\
\text { value }\end{array}$ \\
\hline $\begin{array}{l}\text { Hydraulic con- } \\
\text { ductivity }\end{array}$ & 14.062 & 15.114 & 14.550 \\
$\begin{array}{l}\text { Recharge rate } \\
\begin{array}{l}\text { Maximum depth } \\
\text { of evapotranspira- } \\
\text { tion }\end{array}\end{array}$ & 14.062 & 14.889 & 15.846 \\
$\begin{array}{l}\text { Maximum rate of } \\
\text { evapotranspira- } \\
\text { tion }\end{array}$ & 14.062 & 14.062 & 14.063 \\
\hline
\end{tabular}

${ }^{1}$ The maximum rate of evapotranspiration was limited to 20 percent of the maximum potential rate of 20 inches per year.

\section{Estimates of the Effects of Ground-Water Development}

A simulation of the general effects that might be expected from an increase in ground-water development in the area was done by applying values of specific yield uniformly to the model nodes and evaluating changes in the water budget and water levels produced by the increased discharge. The average specific yield of the aquifer throughout most of the area was estimated from Pettijohn and Chen (1983b) to be between about 12 and 20 percent. For the purposes of demonstrating the effects of increased pumpage, an average specific yield of 16 percent was assumed, although specific yields of 12 and 20 percent were also simulated.

In addition, it was assumed that one additional irrigation well would be drilled in each township annually for 10 years, and two wells per township would be drilled each year for the succeeding 10 years. It also was assumed that the wells would be pumped at the same average rate as the existing wells, $17,700 \mathrm{ft}^{3} / \mathrm{d}$. It was also assumed that pumping outside the study area did not increase. Twenty stress periods, each representing 1 year's pumping, were used to simulate the entire period. Each stress period was simulated using five time steps. 


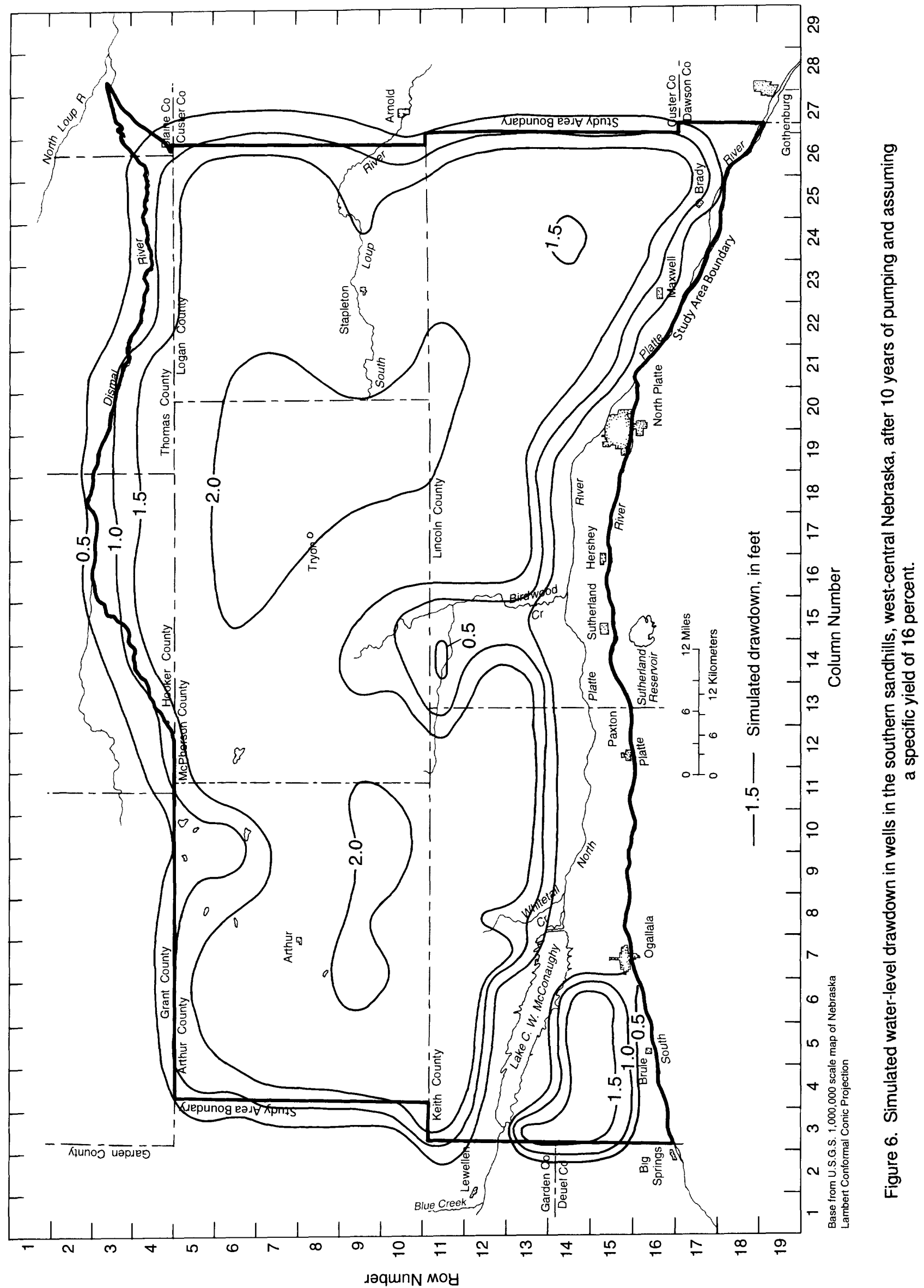

12 SIMULATION OF GROUND-WATER FLOW IN THE HIGH PLAINS AQUIFER, SOUTHERN SANDHILLS AREA, WEST-CENTRAL 


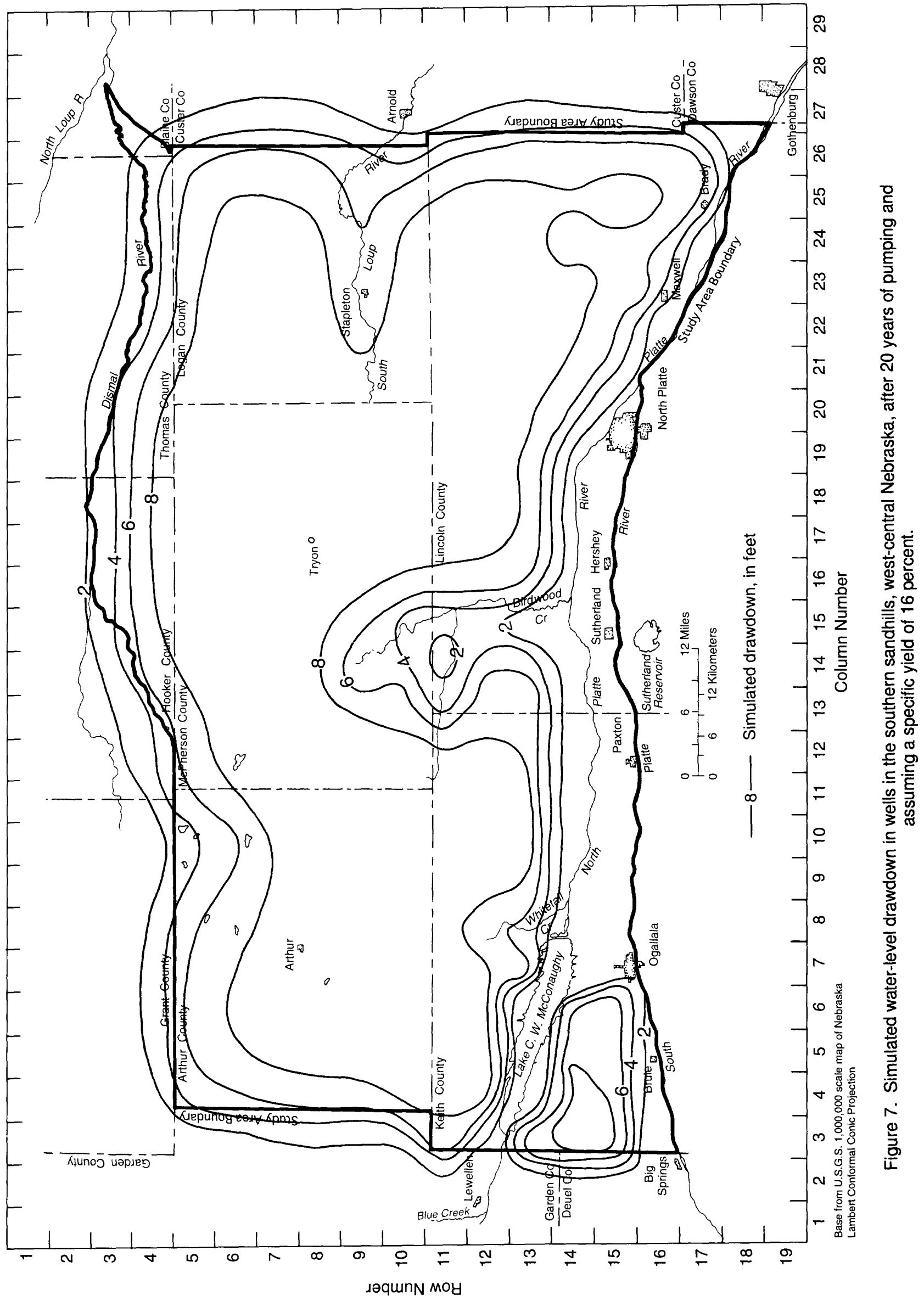


The regional effects after 10 and 20 years of pumping at the increased rates were evaluated. The simulation made using a specific yield of 16 percent is listed in attachment $C$; simulated drawdown after 10 years of pumping is shown in figure 6, and drawdown after 20 years of pumping is shown in figure 7 . Simulated drawdown for assumed specific yields of 12 and 20 percent showed similar patterns; only the magnitude of the drawdown differed from that shown in figures 6 and 7. The effects of specific yield at the location of the greatest simulated drawdown (row 7 , column 19) are shown in table 4.

Table 4. Simulated drawdown after 10 and 20 years of pumping at model row 7 , column 19

[Drawdown values are in feet]

\begin{tabular}{lcc}
\hline \multirow{2}{*}{$\begin{array}{c}\text { Speclfic yield } \\
\text { (percent) }\end{array}$} & \multicolumn{2}{c}{ Drawdown after } \\
\cline { 2 - 3 } & 10 years & 20 years \\
\hline 20 & 1.62 & 7.75 \\
16 & 2.02 & 9.63 \\
12 & 2.68 & 12.69 \\
\hline
\end{tabular}

The simulated water budgets of the study area after 10 and 20 years of pumping are shown in attachment $D$ (using the same zones used to evaluate the steady-state water budget) and the water budget at the end of 20 years of pumping is summarized in table 5. Changes in the water budget of the area due to the increased pumping can be evaluated by comparing tables 1 and 5. After the last time step of stress period 20, pumping (well discharge) had increased $643 \mathrm{ft}^{3} / \mathrm{s}$ from the steady-state simulation. Seventy-three percent of the increased pumping was derived from aquifer storage (the system did not approach steady-state conditions); 12 percent from decreases in discharges to small streams (represented by drains); 6 percent from increased subsurface inflow and decreased subsurface outflow across the boundaries of the study area; 4 percent from decreases in the discharges to the major rivers (or the associated canals and drains); 3 percent from decreases in ground-water evapotranspiration; and 1 percent from decreased discharge to the constant-head nodes representing Lake McConaughy (values do not total 100 percent because of rounding).
Table 5. Simulated water budget for the High Plains aquifer in the study area after 20 years of pumping

[Values are in cubic feet per second]

\begin{tabular}{|c|c|c|c|}
\hline \multicolumn{2}{|c|}{$\begin{array}{c}\text { INFLOW } \\
\text { (Recharge) }\end{array}$} & \multicolumn{2}{|c|}{$\begin{array}{l}\text { OUTFLOW } \\
\text { (Discharge) }\end{array}$} \\
\hline Constant head & 11 & Constant head & 57 \\
\hline Rivers & 15 & Rivers & 350 \\
\hline Boundary inflow & 201 & Boundary outflow & 154 \\
\hline $\begin{array}{l}\text { Recharge from } \\
\text { precipitation }\end{array}$ & 1,129 & Wells & 769 \\
\hline \multirow[t]{2}{*}{ Aquifer storage } & 472 & Drains & 373 \\
\hline & & Evapotranspiration & 126 \\
\hline Total & 1,828 & Total & 1,829 \\
\hline
\end{tabular}

The decrease in the discharge to small streams can be evaluated for selected streams by comparing tables 2 and 6 . The simulated flow decreased $10 \mathrm{ft}^{3} / \mathrm{s}$ in the Dismal River, $7 \mathrm{ft}^{3} / \mathrm{s}$ in Birdwood Creek, $3 \mathrm{ft}^{3} / \mathrm{s}$ in the South Loup River, and $\mathrm{ft}^{3} / \mathrm{s}$ in Whitetail Creek.

Table 6. Simulated discharge to streams in the study area after 20 years of pumping

[Values are in cubic feet per second]

\begin{tabular}{lc}
\hline \multicolumn{1}{c}{ Stream } & Simulated discharge \\
\hline Dismal River & 241 \\
Birdwood Creek & 141 \\
South Loup River & 21 \\
Whitetail Creek & 27 \\
\hline
\end{tabular}

\section{SUMMARY AND CONCLUSIONS}

A numerical model of the High Plains aquifer in the southern sandhills area of west-central Nebraska was prepared using an areal distribution of hydraulic conductivity derived from test-well descriptions and a distribution of recharge based on a soil-moisture budget model. It was necessary to limit the value used for ground-water evapotranspiration to 20 percent of the maximum potential evapotranspiration to successfully calibrate the model against measured ground-water levels. The simulation selected for the steady-state representation of the aquifer system is only one of a 
large number of possible simulations based on different combinations of recharge, evapotranspiration, and hydraulic conductivity that provide almost the same mean absolute error. Because a unique solution was not obtained and because the study area has little existing pumpage, the results of the simulations should be used with caution.

The model generally reproduced the measured hydraulic heads and measured base flows in the area. Local differences between the measured and simulated water levels may have been due to local differences in hydraulic conductivity or recharge from the regional values used for the model. The base flows simulated for the South Loup River and the hydraulic heads simulated near Whitetail Creek and south of the Dismal River did not coincide with the measured values. It is not clear whether these discrepancies represented errors in the model formulation or were the result of nonrepresentative measurements.

The steady-state simulation indicated that the subsurface inflow and outflow at the boundaries of the study area were in balance and that significant percentages of the recharge to the study area discharge to small streams, to rivers, through evapotranspiration, and from wells. Pumpage from wells was estimated on the basis of the assumption that all registered irrigation wells are used to irrigate 135 acres each. Because some wells are unused and some fields are occasionally left fallow, this method probably overestimates the existing pumpage. Nonetheless, wells accounted for less than 10 percent of the total simulated discharge.

The final calibrated simulation used hydraulicconductivity values that were 122 percent, and recharge rates that were 89 percent of the original values used in the model. Sixty-seven percent of the simulated recharge to the High Plains aquifer discharges to rivers, streams, and lakes. Discharges through ground-water evapotranspiration and from pumping wells accounts for 20 percent, with the wells accounting for less than 10 percent of the total discharge, and subsurface boundary outflow accounting for 13 percent.

The model is most sensitive to estimates of recharge and hydraulic conductivity and is least sensitive to small changes in the maximum depth of evapotranspiration. The model is only minimally sensitive to the rate of evapotranspiration, although the mean absolute error continually decreased until the maxi- mum potential rate of evapotranspiration was exceeded. Therefore, it was necessary to limit the simulated rate to the largest potential rate likely to occur.

Effects of future ground-water development in the study area were simulated by adding one pumping well per township per year to the study area for a period of 10 years and then adding two additional wells per township per year for the succeeding 10 years. It was assumed in this simulation that pumping outside the study area did not increase. The results indicated that water-level drawdown in the study area was nearly uniform and that drawdown was small outside the study area. Assuming that the average specific yield of the High Plains aquifer in the study area, 16 percent, applies uniformly to the entire model area, the maximum drawdown after 20 years of pumping would be less than $10 \mathrm{ft}$. Because the pumpage continually increased under this simulation, the aquifer system did not approach steady-state conditions, and 73 percent of the additional water pumped at the end of the 20th year was derived from a reduction in aquifer storage. Although 12 percent of the additional water pumped was balanced by a reduction in the flow of small streams, the reduction in simulated discharge to major rivers was only about 4 percent.

\section{SELECTED REFERENCES}

Diffendal, R.F., Jr., 1991, Geologic map showing configuration of the bedrock surface, North Platte $1^{\circ} \times 2^{\circ}$ quadrangle, Nebraska: U.S. Geological Survey Miscellaneous Investigations Series Map I-2277, 1 sheet, scale 1:250,000.

Dugan, J.T. and Zelt, R.B., in press, Simulation and analysis of soil-water conditions in the Great Plains and adjacent areas, central United States, 1951-80: U.S. Geological Survey Water-Supply Paper 2427.

Goeke, J.W., Peckenpaugh, J.M., Cady, R.E., and Dugan, J.T., 1992, Hydrogeology of parts of the Twin Platte and Middle Republican Natural Resources Districts, southwestern Nebraska: Nebraska Water Survey Paper No. 70,89 p.

Gutentag, E.D., Heimes, F.J., Krothe, N.C., Luckey, R.R., and Weeks, J.B. 1984, Geohydrology of the High Plains aquifer in parts of Colorado, Kansas, Nebraska, New Mexico, Oklahoma, South Dakota, Texas, and Wyoming: U.S. Geological Survey Professional Paper $1400-\mathrm{B}, 63 \mathrm{p}$. 
Harbaugh, A.W., 1990, A computer program for calculating subregional water budgets using results from the U.S. Geological Survey modular three-dimensional finitedifference ground-water flow model: U.S. Geological Survey Open-File Report 90-392, 46 p.

Johnson, M.S., Goeke, J.E., and Engberg, R.A., 1986, Hydrologic data for the southern sandhills area, Nebraska: U.S. Geological Survey Open-File Report 86-411, $136 \mathrm{p}$.

McDonald, M.G., and Harbaugh, A.W., 1988, A modular three-dimensional finite-difference ground-water flow model: U. S. Geological Survey Techniques of WaterResources Investigations, book 6, chap. A1, $586 \mathrm{p}$.

Pettijohn, R.A., and Chen, H.H, 1983a, Geohydrology of the High Plains aquifer system in Nebraska: U.S. Geological Survey Water-Resources Investigations OpenFile Report 82-502, 18 p.

1983b, Hydraulic conductivity, specific yield, and pumpage--High Plains aquifer system, Nebraska: U.S. Geological Survey Water-Resources Investigations Open-File Report 82-4014, 3 sheets.

Swinehart, J.B., and Diffendal, R.F., Jr., 1990, Geology of the pre-dune strata, in Bleed, Ann, and Flowerday, Charles, eds., An atlas of the sandhills: Conservation and Survey Division, Institute of Agriculture and Natural Resources, University of Nebraska-Lincoln Resource Atlas No. 5a, 265 p. 